\title{
Lentibacillus halodurans sp. nov., a moderately halophilic bacterium isolated from a salt lake in Xin-Jiang, China
}

\author{
Sanqing Yuan, ${ }^{1,2}$ Peigen Ren, ${ }^{1}$ Jun Liu, ${ }^{1}$ Yanfen Xue, ${ }^{1}$ Yanhe $\mathrm{Ma}^{1}$ \\ and Peijin Zhou ${ }^{1}$ \\ ${ }^{1}$ State Key Laboratory of Microbial Resources, Institute of Microbiology, Chinese Academy of \\ Sciences, Beijing 100080, China \\ ${ }^{2}$ Graduate School of the Chinese Academy of Sciences, Beijing 100049, China
}

\begin{abstract}
A Gram-positive, rod-shaped, spore-forming and moderately halophilic bacterium (strain 8-1 ${ }^{\top}$ ) was isolated from a sediment sample of a neutral salt lake in Xin-Jiang, China. The strain grew optimally at $30^{\circ} \mathrm{C}, \mathrm{pH} 7.0-7.5$ and $8-12 \%(\mathrm{w} / \mathrm{v}) \mathrm{NaCl}$. The major cellular fatty acids were anteiso- $\mathrm{C}_{15: 0}$, iso- $\mathrm{C}_{15: 0}$ and anteiso- $\mathrm{C}_{17: 0}$. The predominant isoprenoid quinone was MK-7 and the cell-wall peptidoglycan contained meso-diaminopimelic acid. Phosphatidylglycerol, diphosphatidylglycerol and two unidentified glycolipids were found to be the major polar lipid components. The genomic DNA G + C content was $43.4 \mathrm{~mol} \%$. Phylogenetic analysis based on the $16 \mathrm{~S}$ rRNA gene sequence revealed that strain $8-1^{\top}$ was closely related to Lentibacillus salarius KCTC $3911^{\top}(98.0 \%$ sequence similarity) and other recognized species within the genus Lentibacillus (94.5-95.9\%). The level of DNA-DNA relatedness between strain $8-1^{\top}$ and $L$. salarius $\mathrm{KCTC} 3911^{\top}$ was $40 \%$. Based on the phenotypic and genotypic data presented, strain $8-1^{\top}$ is considered to represent a novel species of the genus Lentibacillus, for which the name Lentibacillus halodurans sp. nov. is proposed. The type strain is $8-1^{\top}\left(=\right.$ CGMCC $1.3702^{\top}=$ DSM $\left.18342^{\top}\right)$.
\end{abstract}

Moderately halophilic bacteria (MHB), i.e. those that grow optimally in media containing $3-15 \%(w / v) \quad \mathrm{NaCl}$ (Kushner, 1978), are distributed globally from oceanic to diverse terrestrial saline environments, including salterns, saline soils, salted foods and soda lakes. Numerous MHB are assigned taxonomically to the genera Halobacillus (Spring et al., 1996), Virgibacillus (Heyndrickx et al., 1998), Gracilibacillus (Wainø et al., 1999), Filobacillus (Schlesner et al., 2001), Jeotgalibacillus (Yoon et al., 2001), Lentibacillus (Yoon et al., 2002), Tenuibacillus (Ren \& Zhou, 2005a) and Salinibacillus (Ren \& Zhou, 2005b), many of which were originally affiliated to the genus Bacillus.

In recent years, several Gram-positive MHB belonging to the family Bacillaceae have been isolated from the salt lakes in Xin-Jiang, China (Jeon et al., 2005; Ren \& Zhou, 2005a, b). Here we present phenotypic and genotypic data from a moderately halophilic strain, designated $8-1^{\mathrm{T}}$, and show that this represents a novel species of the genus Lentibacillus.

The sampling site (Ai-Ding Lake), sample collection and treatment and the isolation of MHB were as described by Ren \& Zhou (2005a). Strain $8-1^{\mathrm{T}}$ was grown routinely on

Abbreviation: MHB, moderately halophilic bacteria.

The GenBank/EMBL/DDBJ accession number for the 16S rRNA gene sequence of strain $8-1^{\top}$ is $A Y 321433$.
HM medium (Ventosa et al., 1982) with the addition of $10 \%(\mathrm{w} / \mathrm{v}) \mathrm{NaCl}$. Cell morphology was observed by using an AOM Optical 1-20 light microscope and a transmission electron microscope (Hitachi S-570) as described by Zhu et al. (2003). Gram staining was performed as described by Gerhardt et al. (1981). Motility was determined in wet mounts by using phase-contrast microscopy (AOM Optical 1-20) and by culture in soft-agar medium. The presence of flagella was demonstrated by staining (Kodaka et al., 1982) and transmission electron microscopy. On HM medium with $10 \%(\mathrm{w} / \mathrm{v}) \mathrm{NaCl}$, strain $8-1^{\mathrm{T}}$ formed creamy, circular colonies that were slightly convex at the centre. Cells of strain $8-1^{\mathrm{T}}$ were rod-shaped, measuring approximately $0.5 \times 1.5-2.5 \mu \mathrm{m}$. Cells were non-motile and no flagella were observed. In contrast, Jeon et al. (2005) reported that cells of Lentibacillus salarius KCTC $3911^{\mathrm{T}}$ were motile by means of two flagella on the sides of the cells.

General physiological and biochemical tests were performed as described by Smibert \& Krieg (1981). The $\mathrm{NaCl}$, temperature and $\mathrm{pH}$ ranges for growth of the new isolate were determined as described by Ren \& Zhou (2005a). Utilization of carbon and energy sources was investigated by using basal medium to which appropriate substrates $(0.5 \%$, w/v) had been added (Xin et al., 2001). Twenty-six different saccharides, polysaccharides and sugar alcohols were each used as sole carbon sources. Hydrolysis of starch, casein, 
gelatin and Tweens 20,40, 60 and 80 was determined on a modified HM plate (Ventosa et al., 1982) by replacing the saccharide in the medium with the appropriate substrate. Susceptibility to antibiotics was determined on agarmedium plates by using absorbent paper discs impregnated with antibiotics. Strain $8-1^{\mathrm{T}}$ showed moderate halophily, growing in the presence of $5-30 \%(\mathrm{w} / \mathrm{v}) \mathrm{NaCl}$. It grew optimally on media with $8-12 \%(\mathrm{w} / \mathrm{v}) \mathrm{NaCl}$. Strain $8-1^{\mathrm{T}}$ grew in the $\mathrm{pH}$ range 6.0-9.0 (optimum $\mathrm{pH} 7.0-7.5$ ) and a temperature range of $22-45^{\circ} \mathrm{C}$ (optimum $30^{\circ} \mathrm{C}$ ). Other biochemical properties are detailed in Table 1 and in the species description below.

Cell mass used for extraction of DNA (Sambrook et al., 1989), determination of the cellular fatty acid profile (MIDI Sherlock microbial identification system; Microbial ID) and peptidoglycan composition (Schleifer \& Kandler, 1972) and analysis of polar lipids (Minnikin et al., 1984) and isoprenoid quinones (Collins et al., 1977; Groth et al., 1996) was obtained by cultivating strain $8-1^{\mathrm{T}}$ at $30^{\circ} \mathrm{C}$ and $\mathrm{pH} 7.2$ on $\mathrm{HM}$ medium with $10 \%(\mathrm{w} / \mathrm{v}) \mathrm{NaCl}$. The genomic DNA $\mathrm{G}+\mathrm{C}$ content was determined by the thermal denaturation method according to Marmur \& Doty (1962). The major isoprenoid quinone of strain $8-1^{\mathrm{T}}$ was MK-7. Strain $8-1^{\mathrm{T}}$ contained meso-diaminopimelic acid (meso-DAP) as a diagnostic diamino acid in the cell-wall peptidoglycan; by contrast, Jeon et al. (2005) reported that L. salarius KCTC $3911^{\mathrm{T}}$ did not contain any diamino acids in its cell-wall peptidoglycan. The major polar lipids of strain $8-1^{\mathrm{T}}$ were phosphatidylglycerol, diphosphatidylglycerol and two unidentified glycolipids. Cellular fatty acid analysis of strain 8$1^{\mathrm{T}}$ revealed that the main components were anteiso- $\mathrm{C}_{15: 0}$ $(42.41 \%)$, iso- $\mathrm{C}_{15: 0}(20.73 \%)$, anteiso- $\mathrm{C}_{17: 0}(17.17 \%)$, iso- $\mathrm{C}_{16: 0}(7.73 \%)$, iso- $\mathrm{C}_{17: 0}(5.3 \%)$, iso- $\mathrm{C}_{14: 0}(3.1 \%)$ and $\mathrm{C}_{16: 0}(2.16 \%)$, contrasting with several closely related species of the genus Lentibacillus. The genomic DNA G + C content of strain $8-1^{\mathrm{T}}$ was $43.4 \mathrm{~mol} \%$, a value similar to those reported for L. salarius KCTC $3911^{\mathrm{T}}(43 \mathrm{~mol} \%)$ and Lentibacillus salicampi KCCM $41560^{\mathrm{T}}$ (44 mol\%). Characteristics that are useful in the differentiation of strain $8-1^{\mathrm{T}}$ from several closely related taxa are shown in Table 1 .

The 16S rRNA gene of strain $8-1^{\mathrm{T}}$ was amplified by PCR with universal primers as described by Duckworth et al. (1996). The almost-complete nucleotide sequence (1466 bp) was determined by direct sequencing and compared with available $16 \mathrm{~S}$ rRNA gene sequences in the GenBank database by using the BLAST program. Multiple

Table 1. Differential characteristics of strain $8-1^{\top}$ and other species of the genus Lentibacillus

Strains: 1, strain $8-1^{\mathrm{T}}$; 2, L. salarius KCTC $3911^{\mathrm{T}}$ (data from Jeon et al., 2005); 3, L. salicampi KCCM 41560 ${ }^{\mathrm{T}}$ (Yoon et al., 2002); 4, L. juripiscarius JCM $12147^{\mathrm{T}}$ (Namwong et al., 2005); 5, L. lacisalsi KCTC $3915^{\mathrm{T}}$ (Lim et al., 2005); 6, L. halophilus JCM $12149^{\mathrm{T}}$ (Tanasupawat et al., 2006). +, Positive; -, negative; W, weak; ND, no data.

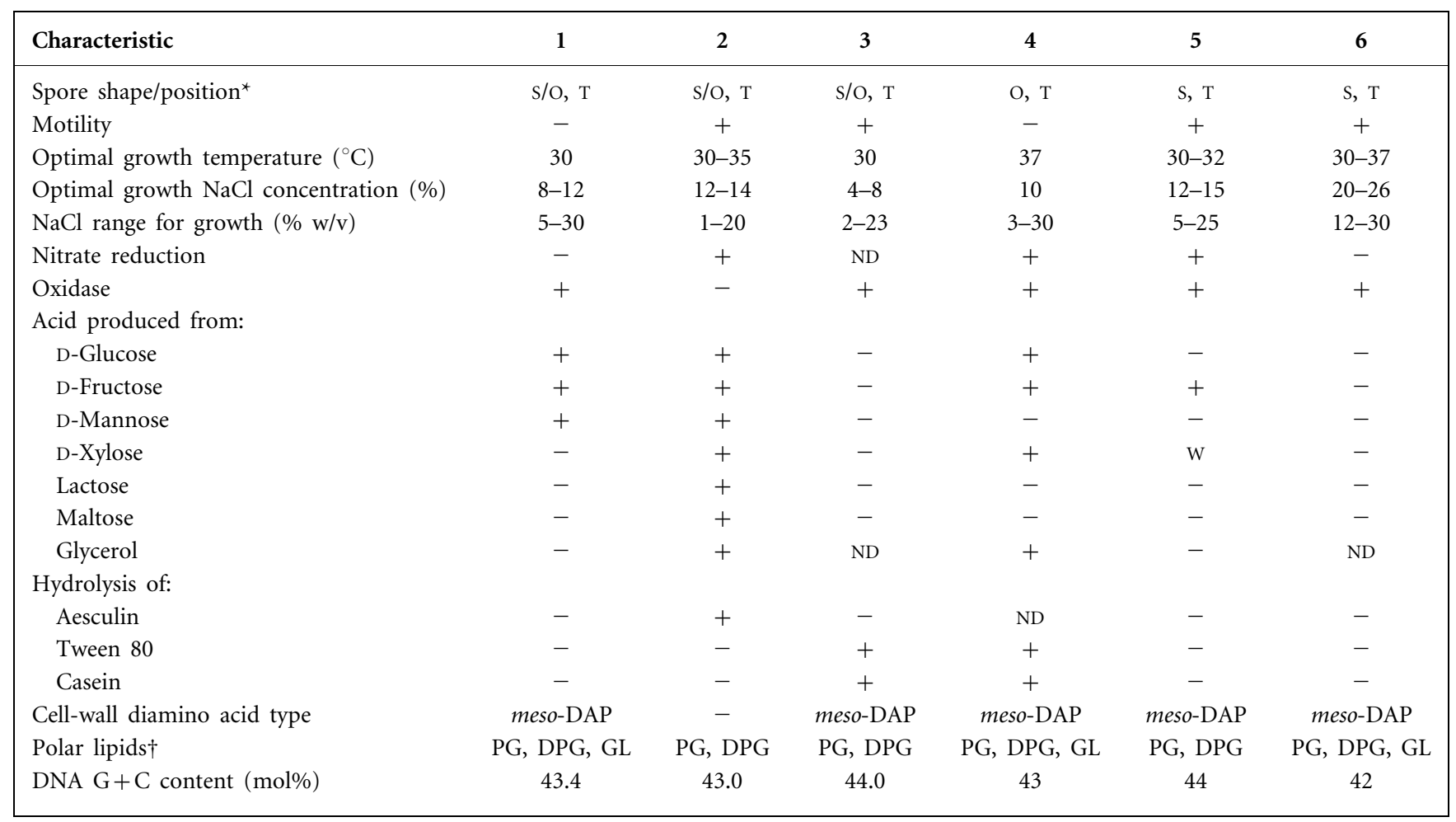

${ }^{\star} \mathrm{O}$, Oval; s, spherical; T, terminal.

†DPG, Diphosphatidylglycerol; GL, unknown glycolipid(s); PG, phosphatidylglycerol. 
alignment with closely related members was performed by using the CLUSTAL W program (Thompson et al., 1994). Ambiguous and unalignable bases were manually omitted and the phylogenetic tree was then constructed by using the neighbour-joining, minimum-evolution and maximumparsimony methods in the MEGA program (version 3.1; Kumar et al., 2004). The stability of relationships was assessed by bootstrap analysis (1000 replications). The phylogenetic tree (Fig. 1) based on the neighbour-joining method indicated that strain $8-1^{\mathrm{T}}$ formed a coherent cluster with recognized species of the genus Lentibacillus. Strain 8$1^{\mathrm{T}}$ was related most closely to $L$. salarius KCTC $3911^{\mathrm{T}}$ (98.0\% 16S rRNA gene sequence similarity) and showed levels of similarity of $94.5-95.9 \%$ to other recognized species of the genus Lentibacillus. Similar tree topologies were obtained with the maximum-likelihood and maximum-parsimony algorithms (data not shown). DNA-DNA hybridization was performed by the spectrophotometric renaturation rate method (Huß et al., 1983; De Ley et al., 1970) to determine the level of relatedness between strain $8-1^{\mathrm{T}}$ and L. salarius KCTC $3911^{\mathrm{T}}$, its closest relative as determined from 16S rRNA gene sequence analysis. The level of DNA-DNA relatedness between strain $8-1^{\mathrm{T}}$ and $L$. salarius KCTC $3911^{\mathrm{T}}$ was $40 \%$ (mean of three independent experiments, which did not differ by more than $6 \%$ ). In combination with $16 \mathrm{~S}$ rRNA gene sequence data, this indicates that strain $8-1^{\mathrm{T}}$ is not genotypically related to any recognized species of the genus Lentibacillus (Stackebrandt \& Goebel, 1994).

On the basis of the data presented, strain $8-1^{\mathrm{T}}$ is considered to represent a novel species of the genus Lentibacillus, for which the name Lentibacillus halodurans sp. nov. is proposed.

\section{Description of Lentibacillus halodurans sp. nov.}

Lentibacillus halodurans (ha.lo.du'rans. Gr. n. hals salt; L. pres. part. durans enduring; N.L. part. adj. halodurans saltenduring).
Cells are Gram-positive, rod-shaped, $0.5 \times 1.5-2.5 \mu \mathrm{m}$, nonmotile and strictly aerobic. Spherical or oval endospores form at the cell-terminal position in swollen sporangia. Colonies are white, slightly convex and $4-5 \mathrm{~mm}$ in diameter with regular margins after 2 days cultivation on HM medium with $10 \%(\mathrm{w} / \mathrm{v}) \mathrm{NaCl}$. Oxidase- and catalase-positive but ureasenegative. Growth occurs at a temperature range of $22-45^{\circ} \mathrm{C}$ (optimum $30^{\circ} \mathrm{C}$ ) and $\mathrm{NaCl}$ concentration of between 5 and $30 \%(w / v)$ (optimum 8-12\%). No growth occurs without $\mathrm{NaCl}$. The $\mathrm{pH}$ range for growth is 6.0-9.0 (optimum $\mathrm{pH}$ 7.0-7.5). Nitrate is not reduced to nitrite. D-Glucose, D-mannose, D-fructose, cellobiose, L-sorbose, inulin, D-raffinose, D-galactose, salicin, lactose, sucrose, aesculin, maltose, mannitol, melibiose, D-sorbose, trehalose, dulcitol, glycerol, inositol, erythritol, melezitose, arabinose, rhamnose and xylose are used as carbon sources. Acid is produced from Dmannose, D-fructose and D-glucose. Gelatin and Tween 40 are hydrolysed, but casein, starch, aesculin, and Tweens 20 and 80 are not. Cells are resistant to norfloxacin $(10 \mu \mathrm{g})$, neomycin $(30 \mu \mathrm{g})$, bacitracin $(0.04 \mathrm{U})$, tetracycline $(30 \mu \mathrm{g})$, streptomycin $(10 \mu \mathrm{g})$, chloramphenicol $(30 \mu \mathrm{g})$, kanamycin $(30 \mu \mathrm{g})$ and penicillin $\mathrm{G}(10 \mathrm{U})$, but susceptible to novobiocin $(30 \mu \mathrm{g})$, rifampicin $(5 \mu \mathrm{g})$, erythromycin $(15 \mu \mathrm{g})$, ciprofloxacin $(5 \mu \mathrm{g})$, vancomycin $(30 \mu \mathrm{g})$ and ampicillin $(10 \mu \mathrm{g})$. The predominant menaquinone is MK-7. The diagnostic diamino acid in the cell-wall peptidoglycan is meso-DAP, and major polar lipids are phosphatidylglycerol, diphosphatidylglycerol and two unidentified glycolipids. The major fatty acids are

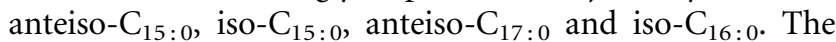
genomic DNA G $+\mathrm{C}$ content is $43.4 \mathrm{~mol} \%\left(T_{\mathrm{m}}\right)$.

The type strain, $8-1^{\mathrm{T}}\left(=\right.$ CGMCC $1.3702^{\mathrm{T}}=$ DSM $\left.18342^{\mathrm{T}}\right)$, was isolated from a sediment sample of a neutral salt lake in Xin-Jiang, China.

\section{Acknowledgements}

This work was supported by grants from the Ministry of Science and Technology of China (973 Programs, 2004CB719605 and 2003CB716001) and the Chinese Academy of Sciences (Knowledge Innovation program, KSCX2-SW-33).

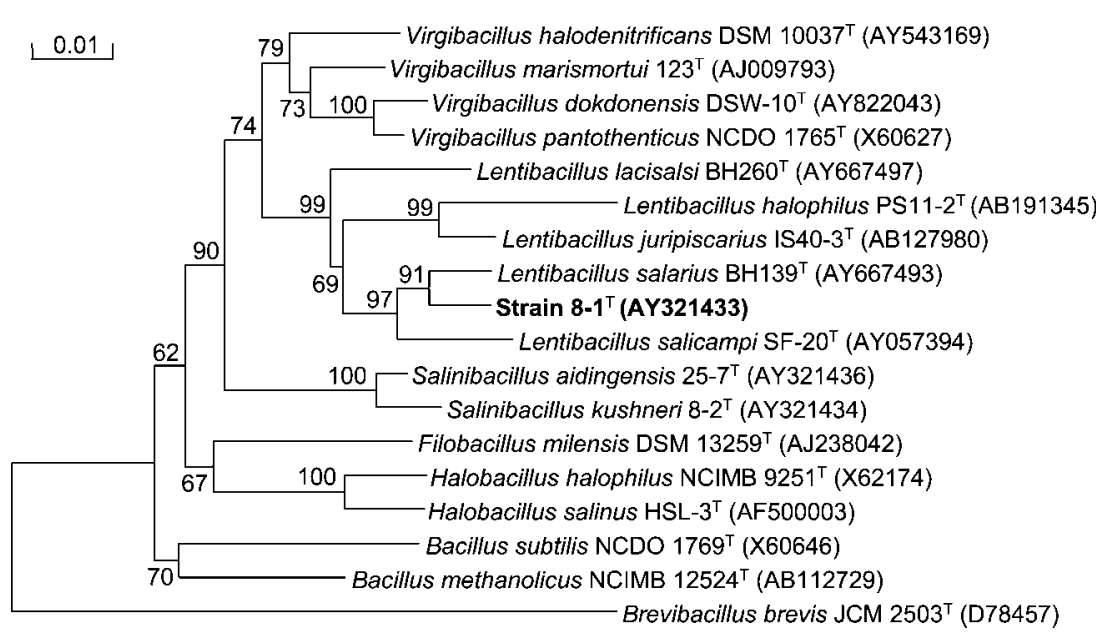

Fig. 1. Phylogenetic tree showing the relationships of strain $8-1^{\top}$ and other related species, based on 16S rRNA gene sequences. The tree was constructed with the neighbour-joining method; bootstrap values $>50 \%$ based on 1000 replications are given at branch points. Bar, 0.01 substitutions per nucleotide position. 


\section{References}

Collins, M. D., Pirouz, T., Goodfellow, M. \& Minnikin, D. E. (1977). Distribution of menaquinones in actinomycetes and corynebacteria. $J$ Gen Microbiol 100, 221-230.

De Ley, J., Cattoir, H. \& Reynaerts, A. (1970). The quantitative measurement of DNA hybridization from renaturation rates. Eur J Biochem 12, 133-142.

Duckworth, A. W., Grant, W. D., Jones, B. E. \& Steenbergen, R. V. (1996). Phylogenetic diversity of soda lake alkaliphiles. FEMS Microbiol Ecol 19, 181-191.

Gerhardt, P., Murray, R. G. E., Costilow, R. N., Nester, E. W., Woods, W. A., Krieg, N. R. \& Philips, G. B. (editors) (1981). Manual of Methods for General Bacteriology. Washington, DC: American Society for Microbiology.

Groth, I., Schumann, P., Weiss, N., Martin, K. \& Rainey, F. A. (1996). Agrococcus jenensis gen. nov., sp. nov., a new genus of actinomycetes with diaminobutyric acid in the cell wall. Int J Syst Bacteriol 46, 234-239.

Heyndrickx, M., Lebbe, L., Kersters, K., De Vos, P., Forsyth, G. \& Logan, N. A. (1998). Virgibacillus: a new genus to accommodate Bacillus pantothenticus (Proom and Knight 1950). Emended description of Virgibacillus pantothenticus. Int J Syst Bacteriol 48, 99-106.

Huß, V. A. R., Festl, H. \& Schleifer, K. H. (1983). Studies on the spectrophotometric determination of DNA hybridization from renaturation rates. Syst Appl Microbiol 4, 184-192.

Jeon, C. O., Lim, J.-M., Lee, J. C., Lee, G. S., Lee, J.-M., Xu, L.-H., Jiang, C.-L. \& Kim, C.-J. (2005). Lentibacillus salarius sp. nov., isolated from saline sediment in China, and emended description of the genus Lentibacillus. Int J Syst Evol Microbiol 55, 1339-1343.

Kodaka, H., Armfield, A. Y., Lombard, G. L. \& Dowell, V. R., Jr (1982). Practical procedure for demonstrating bacterial flagella. J Clin Microbiol 16, 948-952.

Kumar, S., Tamura, K. \& Nei, M. (2004). MEGA3: integrated software for molecular evolutionary genetics analysis and sequence alignment. Brief Bioinform 5, 150-163.

Kushner, D. J. (1978). Life in high salt and solute concentrations: halophilic bacteria. In Microbial Life in Extreme Environments, pp. 317-368. Edited by D. J. Kushner. London: Academic Press.

Lim, J.-M., Jeon, C. O., Song, S.-M., Lee, J.-C., Ju, Y. J., Xu, L.-H., Jiang, C.-L. \& Kim, C.-J. (2005). Lentibacillus lacisalsi sp. nov., a moderately halophilic bacterium isolated from a saline lake in China. Int J Syst Evol Microbiol 55, 1805-1809.

Marmur, J. \& Doty, P. (1962). Determination of the base composition of deoxyribonucleic acid from its thermal denaturation temperature. J Mol Biol 4, 109-118.

Minnikin, D. E., O’Donnell, A. G., Goodfellow, M., Alderson, G., Athalye, M., Schaal, A. \& Parlett, J. H. (1984). An integrated procedure for the extraction of bacterial isoprenoid quinones and polar lipids. J Microbiol Methods 2, 233-241.

Namwong, S., Tanasupawat, S., Smitinont, T., Visessanguan, W., Kudo, T. \& Itoh, T. (2005). Isolation of Lentibacillus salicampi strains and Lentibacillus juripiscarius sp. nov. from fish sauce in Thailand. Int J Syst Evol Microbiol 55, 315-320.

Ren, P. G. \& Zhou, P. J. (2005a). Tenuibacillus multivorans gen. nov., sp. nov., a moderately halophilic bacterium isolated from saline soil in Xin-Jiang, China. Int J Syst Evol Microbiol 55, 95-99.

Ren, P. G. \& Zhou, P. J. (2005b). Salinibacillus aidingensis gen. nov., sp. nov. and Salinibacillus kushneri sp. nov., moderately halophilic bacteria isolated from a neutral saline lake in Xin-Jiang, China. Int $J$ Syst Evol Microbiol 55, 949-953.

Sambrook, J., Fritsch, E. F. \& Maniatis, T. (1989). Molecular Cloning: a Laboratory Manual, 2nd edn. Cold Spring Harbor, NY: Cold Spring Harbor Laboratory.

Schleifer, K. H. \& Kandler, O. (1972). Peptidoglycan types of bacterial cell walls and their taxonomic implications. Bacteriol Rev 36, 407-477.

Schlesner, H., Lawson, P. A., Collins, M. D., Weiss, N., Wehmeyer, U., Völker, H. \& Thomm, M. (2001). Filobacillus milensis gen. nov., sp. nov., a new halophilic spore-forming bacterium with Orn-D-Glutype peptidoglycan. Int J Syst Evol Microbiol 51, 425-431.

Smibert, R. M. \& Krieg, N. R. (1981). Phenotypic characterization. In Manual of Methods for General Microbiology, pp. 611-654. Edited by P. Gerhardt, R. G. E. Murray, R. N. Costilow, E. W. Nester, W. A. Woods, N. R. Krieg \& G. B. Philips. Washington, DC: American Society for Microbiology.

Spring, S., Ludwig, W., Marquez, M. C., Ventosa, A. \& Schleifer, K. H. (1996). Halobacillus gen. nov., with descriptions of Halobacillus litoralis sp. nov., and Halobacillus trueperi sp. nov., and transfer of Sporosarcina halophila to Halobacillus halophilus comb. nov. Int J Syst Bacteriol 46, 492-496.

Stackebrandt, E. \& Goebel, B. M. (1994). Taxonomic note: a place for DNA-DNA reassociation and 16S rRNA sequence analysis in the present species definition in bacteriology. Int J Syst Bacteriol 44, 846-849.

Tanasupawat, S., Pakdeeto, A., Namwong, S., Thawai, C., Kudo, T. \& Itoh, T. (2006). Lentibacillus halophilus sp. nov., from fish sauce in Thailand. Int J Syst Evol Microbiol 56, 1859-1863.

Thompson, J. D., Higgins, D. G. \& Gibson, T. J. (1994). CLUSTAL W: improving the sensitivity of progressive multiple sequence alignment through sequence weighting, position-specific gap penalties and weight matrix choice. Nucleic Acids Res 22, 4673-4680.

Ventosa, A., Quesada, E., Rodriguez-Valera, F., Ruiz-Berraquero, F. \& Ramos-Cormenzana, A. (1982). Numerical taxonomy of moderately halophilic Gram-negative rods. J Gen Microbiol 128, 1959-1968.

Wainø, M., Tindall, B. J., Schumann, P. \& Ingvorsen, K. (1999). Gracilibacillus gen. nov., with description of Gracilibacillus halotolerans gen. nov., sp. nov.; transfer of Bacillus dipsosauri to Gracilibacillus dipsosauri comb. nov., and Bacillus salexigens to the genus Salibacillus gen. nov., as Salibacillus salexigens comb. nov. Int J Syst Bacteriol 49, 821-831.

Xin, H., Itoh, T., Zhou, P., Suzuki, K. \& Nakase, T. (2001). Natronobacterium nitratireducens sp. nov., a haloalkaliphilic archaeon isolated from a soda lake in China. Int J Syst Evol Microbiol 51, $1825-1829$.

Yoon, J.-H., Weiss, N., Lee, K.-C., Lee, I.-S., Kang, K. H. \& Park, Y.-H. (2001). Jeotgalibacillus alimentarius gen. nov., sp. nov., a novel bacterium isolated from jeotgal with L-lysine in the cell wall, and reclassification of Bacillus marinus Rüger 1983 as Marinibacillus marinus gen. nov., comb. nov. Int J Syst Evol Microbiol 51, 20872093.

Yoon, J.-H., Kang, K. H. \& Park, Y.-H. (2002). Lentibacillus salicampi gen. nov., sp. nov., a moderately halophilic bacterium isolated from a salt field in Korea. Int J Syst Evol Microbiol 52, 2043-2048.

Zhu, F., Wang, S. \& Zhou, P. (2003). Flavobacterium xinjiangense sp. nov. and Flavobacterium omnivorum sp. nov., novel psychrophiles from the China No. 1 glacier. Int J Syst Evol Microbiol 53, 853-857. 